\title{
THE VOCATIONAL ASPECT OF COMMERCIAL GEOGRAPHY.
}

\author{
By Alrson E. Aitchison, \\ Teachers' College, Cedar Falls, Lowa.
}

Whether one defines commercial geography as that branch of geography which traces the influence of natural factors in the production, transportation and exchange of commodities or limits it, as some would, merely to the influence of those factors in the transportation and exchange, the same demands which called it to a place in the curriculum of the ordinary high school some years ago, now call for its retention in the courses in the vocational high school.

In the early days of our country's history when the farm home was the center of various productive activities which supplied very largely the simple wants of the household, the child grew up with an intimate knowledge of many of the processes involved in the industries which furnished his food, clothing and shelter. This stage lasted long in America as we possessed for scores of years, a long western frontier, remotely situated from the factories which grew up in the path it had left. In those early days when employer and employee were identical, when capital and labor agreed, when the interests of the community were not so diversified, town and country were not far removed in sympathy, one from the other, the processes of production were simple, transportation was too costly to be extensive and exchange involved no complicated system of wholesalers, drummers, retailers and numberless middle men. In these later days of large urban centers, of little contact between town and country life; these days of great factory systems, of division of labor and segregation and centralization of industries, the child is cut off from all practical knowledge of all these things and because of our complex commercial system, he misses many of the points of contact between his life and the activities of others and loses sight altogether of his relation to the industries which condition his own comfort and progress.

A present day writer on education has said: "The tendency of modern education is to lessen the gap that has long existed between school and life." This in part will be the work of the vocational schools, yet there is danger in these schools, that the vocational part of the work may be too violently or, perhaps, too distantly separated from those studies which we have been justly regarding necessary as the basis of a good education. 
There are some branches that in themselves contain the elements which will bring into closer union the vocational studies, the natural materials of which they make use of and the scientific world which has improved and made possible the industries as they exist today.' Commercial geography may properly be considered one of these linking subjects. A boy in the manual training shop may be working at the forge-if his commercial geography has taught him the location of the great iron ore beds of the United States; the immense transportation systems which are needed to carry the ore to the blast furnaces of Pennsylvania, Ohio, or Illinois; has given him some idea of the work done in preparing the pig iron; has shown him the importance of the iron and steel industry in the economy of the country and its benefit to the United States in its struggle for commercial rank; his work may be no better so far as the mechanical output is concerned; but it has attained a different setting and he realizes his relation to and his dependence upon other laborers scattered throughout a dozen states.

Commercial geography gathers up the loose ends left in the other science studies and unifies them by showing their relation to human society and human progress. Take for example the wheat growing industry. His work in the other sciences has given him the basal facts for interpreting correctly the climatic and soil conditions which determine the location of the world's great wheat fields, as soon as he learns from his commercial geography the specific requirements which wheat demands. His physical geography enables him to say not only, where the rainfall is enough and not too much but why these conditions exist where they do and why they can not be expected in other places. His geology explains for him the soil conditions, his agriculture, why certain soils are adapted ot wheat growing-his botany shows him the wheat as a plant. Now, the commercial geography, at this point, gathers these facts together and shows why, because of these existing conditions, great transportation problems have had to be solved; enormous milling plants have come into existence and large cities have grown about them. It is a long story from the great ice sheet which was indirectly responsible for the level floor of the Red River Valley to the loaf of bread made by the girl in the cooking class but it is a study full of human interest, and one whose perusal will make the girl better able to understand some of the economic problems which face the country's future. 
At this point in the discussion one statement must be made out of justice to the study itself. So long as commercial geography in the high school must be taught by-anyone who happens to have a vacant period, be he German teacher, Latin teacher, or History teacher; by some one who has had no training in it or a kindred subject, it can have no definite relation to vocational subjects or, for that matter, to any other subjects. It will remain a unique and perhaps ornamental catch-all, useful as a piece of busy work but falling as far short of the good' it might accomplish as the ordinary relief map falls short of the topography which it is meant to represent. The commerce of the world depends so largely upon physical and climatic factors that commercial geography, to give the best results, should be studied by pupils who have had a course in physiography. This is often not practicable. If the pupil has been well taught the geography ordinarily given in the grades and the teacher understands the subject matter well enough to discriminate between essentials and non-essentials, a fairly satisfactory course may be given without a preliminary course in physical geography. This then is a double reason why the teacher of commercial geography should be well prepared. Too many sins have already been committed in the name of the subject in the ordinary high schools to make advisable the committing of any more in the vocational schools.

The points at which commercial geography and the vocational subjects come into contact are numerous. For instance in the special courses offered in sewing a knowledge of the textiles from the geographic side, the parts of the world from which they come, the conditions under which they are produced and the centers where they are manufactured is very desirable. The boy working with the turning lathe works more as an intelligent citizen should work, with a greater appreciation of the value of the raw' material which he handles, if he knows something of our dwindling lumber supply and the immense drain which we are making upon it yearly. A class in animal husbandry have wider horizons if they understand the reasons for the location of the great grazing regions of the United States-and their relation to the corn growing sections and to the great packing centers. In all commercial schools the importance of the study has long been recognized and one or two semesters or terms of it have been required.

To look at this from another standpoint any subject, any branch of geography which helps to familiarize the student with the exact locations of places, is of great benefit to him. The ignorance of 
the ordinary high school or normal school, yes, or university, student on this point is appalling. In a test made on a class of university students, in one of the leading universities in the country, within the past year a number were unable to write the names of all the states into an outline map without making several mistakes. The same test tried last summer term with normal school students showed an unbelievable number of errors; Maine in southern United States; Michigan in Wisconsin; Virginia in New England; and other errors of equal magnitude. Cities were located anywhere and everywhere-New York a couple of hundred miles inland; Chicago a hundred miles from the lake; Minneapolis not within hailing distance of the falls; Galveston in central Texas. A study of these errors convinces one that the students examined had connected the cities in question with none of the causes which contributed to their growth, and that their retention was simply an act of memory. Commercial geography helps in fixing location because the reasons for the development of the city are emphasized. It would seem that one who has studied New York from the standpoint of its commercial relations to European countries would hardly be likely to think it near Syracuse or Rochester.

You who are not in sympathy with the subject may say much of this information which has been mentioned should be gained as a matter of general information from newspapers, from magazines, from the geography in the grades. Papers and magazines are not so accessible to all as they are to us; the geography in the common school generally ends with the seventh grade. If one stops to think of the endless arguments and speculations he has often heard made by people who have read an item in the newspapers concerning some place of which they knew nothing, he is forced to admit that a little accurate information concerning the products or industries of the place would sometimes have shown the absurdity of the whole discussion. For example; one might have judged from the wild statements made at the time of the great discussions on Canadian reciprocity, that the number of hides to be shipped into the United States from that country would seriously damage our business. As a matter of fact the total number of cattle in Canada very little exceeds that in the state of lowa alone. As some one has cleverly said, "One might think, from the outcry against Canadian hides, that Canadian stock growers harvested a crop of hides from their cattle every year." Painful investments have been made in good farm lands 
in the pine barrens, in irrigated fruit lands that had no markets, in northern farm lands with too short seasons, which might have been saved had people been trained to look on the geographical side of some of these commercial ventures.

Finally the last great reason for teaching commercial geography in the vocational high schools, a large per cent of these students go from the high school to the business world and any subject which helps them to take a more intelligent, more rational, more sympathetic view of human beings working under more favorable or more adverse conditions in other parts of the world, any subject which helps them to realize the dependency of one group of people upon another or to grasp more fully the dignity of their own labor in its relation to the whole scheme is well worth the time and effort which may be spent upon it.

\section{AMERICA AS A GREAT RADIUM COUNTRY.}

The special warrant for radium conservation in America is the fact that this country has become the greatest recognized source of the element. Joachimsthal, Austria, has been popularly regarded as the most important radium-producing district of the world, but the conclusion is a wrong one. During the last two years the carnotite ores of Southwestern Colorado and eastern. Utah have yielded more radium than has been produced from the mines of Austria. The production was effected in Europe, it is true, but the origin of the raw material was America. In the future our country will continue to command the radium yield, which will come not only from the carnotite deposits, but from the pitchblende ores in Gilpin county, Colorado; these being the best known sources in the United States. It is not fair to the nation that we should not possess our own product, reduce it here, and control the radium supply for the service of our own scientific men. The significant thing about the radium situation, from the point of view of the laboratory, is that small amounts of the salts may not be expected to yield adequate results. It requires a considerable amount to enable the experimenter to bring his results within the range of fairly accurate observation. Dealing as he does with forces that are only indirectly measurable, and then only by the most delicate apparatus, he is bound to feel the lack of such quantities as may bring his notations within the range of certainty. Much emphasis has been laid upon the applications of radium to medical investigation, but we cannot give up the view that the broader benefits to pure science of the revelations concerning the constitution of matter should receive first consideration from the people. The reports which now and then creep into the press concerning the profound investigations of the radium workers are not a mere appeal to popular imagination, but the result of the most momentous revelations to chemistry since the discovery of the periodic law. They go deeper than the periodic law and bring us into an order of things that will require many a year to delve into. Radium seems so important to the wotld of science that it possesses a peculiar sanctity, and therein we find the explanation of the professional competition for the possession of it.-Mining Science. 